\title{
Tipe modifikasi fonem kata serapan asing ke dalam bahasa Indonesia pada surat kabar online berbahasa Indonesia
}

\section{Gigit Mujianto $^{\mathrm{I}^{*}}$, Sudjalil ${ }^{2}$}

Pendidikan Bahasa Indonesia, Fakultas Keguruan dan Ilmu Pendidikan, Universitas Muhammadiyah Malang, Jl. Raya Tlogomas 246 Malang, Indonesia

Igigit@umm.ac.id, sudjalil_63@yahoo.com²

*Corresponding author: gigit@umm.ac.id

\begin{abstract}
Sejarah Artikel Diterima: I4 Februari 202I Direvisi: I2 April 202I Tersedia Daring: 27 April 202I ABSTRAK

Sering digunakannya kata serapan asing ke dalam bahasa Indonesia dalam surat kabar berbahasa Indonesia, akan berdampak pada pemekaran kosakata bahasa Indonesia. Terkait dengan pemerkayaan kosakata bahasa Indonesia, penelitian mengenai tipe modifikasi fonem kata serapan asing ke dalam bahasa Indonesia pada surat kabar berbahasa Indonesia jawa pos.com perlu dilakukan terutama untuk menemukan perubahan struktur fonem pada kata serapan asing. Penelitian ini bertujuan untuk mendeskripsikan tipe modifikasi fonem kata serapan asing ke dalam bahasa Indonesia pada surat kabar online berbahasa Indonesia. Jenis penelitian ini adalah penelitian kualitatif, pendekatan yang digunakan adalah model analisis morfologis. Sumber data dalam penelitian ini adalah surat kabar Jawa Pos online edisi Maret 2020 pada rubrik sport, informasi, bisnis, ekonomi, politik, dan fashion. Data dalam penelitian ini adalah berupa kata serapan asing ke dalam bahasa Indonesia yang terdapat dalam surat kabar Jawa Pos online edisi Maret 2020. Teknik pengumpulan data dalam penelitian ini menggunakan teknik observasi dan dokumentasi. Analisis data yang digunakan dalam penelitian ini adalah analisis data model Miles dan Hubberman. Dari hasil penelitian ditemukan 8 tipe modifikasi fonem pada kata serapan bahasa asing ke dalam bahasa Indonesia yang telah ditemukan dalam penelitian, yakni (I) tipe tanpa penyesuaian ejaan (TTPE), (2) tipe penyesuaian ejaan (TPE), (3) tipe penyesuaian gugus fonem (TPGF), (4) tipe penyesuaian sufiks asing (TPSA), (5) tipe jejeran konsonan atau vokal kembar (TJKVK), (6) tipe gabung I (penggabungan TPE dan TPGF), (7) tipe gabung II (penggabungan TPE dan TPSA), dan (8) tipe gabung III (penggabungan TPGF dan TJKVK). Perkembangan kosakata serapan perlu dilakukan untuk melengkapi kekurangan-kekurangan jenis kata, ungkapan, istilah yang mampu mewadahi dan mengungkapkan aspek-aspek kehidupan, kejiwaan masyarakatnya, serta ilmu pengetahuan dan teknologi.

Kata Kunci Kata serapan asing, Tipe modifikasi fonem

ABSTRACT

The frequent use of foreign loanwords in Indonesian newspapers may influence the Indonesian vocabulary expansion. Regarding this matter, research on the phoneme modification type of foreign loanwords into Indonesian in the Indonesian language newspaper, jawapos.com needs to be done to find changes in the phoneme structures of foreign loanwords. This study aimed at describing the type of phoneme modification of foreign loan words into Indonesian in Indonesian language online newspapers. It was qualitative research with the approach of model analysis. The data source was the online edition of Jawa Pos newspaper in March 2020 on sports, information, business, economy, politics and fashion rubrics. The data were in the form of Indonesian loanwords in the online edition of Jawa Pos newspaper in March 2020. Techniques to gather the data were observation and documentation. The data analysis used analysis model of Miles and Hubberman. From the results of the study, it was found that eight types of phoneme modifications were found in the Indonesian language absorption words, namely (I) no-displaying spelling type (TTPE), (2) spelling type (TPE), (3) phoneme group type TPGF), (4) single total type (TPSA), (5) consonant line type or twin vowels (TJKVK), (6) combined type I (combining TPE and TPGF), (7) combined type II (combining TPE and TPSA ), and (8) combined type III (merging TPGF and TJKVK). The development of borrowed vocabulary needs to be done to complement the deficiencies of the types of words, expressions, and terms that express aspects of life, psychological state of people, as well as science and technology.
\end{abstract}

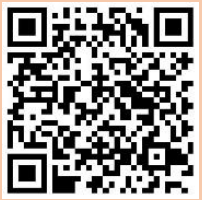

Copyright@202I, Gigit Mujianto, Sudjalil This is an open access article under the $\mathrm{CC}-\mathrm{BY}-3.0$ license

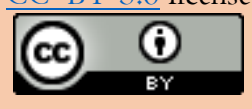

\section{Keywords foreign loanwords, phoneme modification}

How to Cite Mujianto, G., \& Sudjalil, S. (202I). Tipe modifikasi fonem kata serapan asing ke dalam bahasa Indonesia pada surat kabar online berbahasa Indonesia. KEMBARA: Jurnal Keilmuan, Bahasa, Sastra dan Pengajarannya (e-Journal), 7(I), I-I9. doi: https://doi.org/I0.22219/kembara.v7iI.I6206 


\section{PENDAHULUAN}

Perkembangan ilmu pengetahuan dan teknologi saat ini terus bergerak secara masif ke segala bidang kehidupan masyarakat Indonesia (Mabruroh, 2017). Gerakan perkembangan tersebut akan berdampak kepada pemenuhan kebutuhan dan kesejahteraan masyarakatnya. Untuk mengatasi dampak tersebut banyak cara yang harus dilakukan masyarakat Indonesia, antara lain penguasaan bahasa (Sundasewu, 2015). Melalui pengalaman historis yang cukup lama, bahasa Indonesia sudah melakukan pembenahan ejaan dan tanda baca, pilihan kata (Putradi, 2016), dan bahkan pembakuan unsur-unsur bahasa asing yang masuk ke dalam bahasa Indonesia (Meysitta, 2018).

Dalam perkembangannya, penyerapan unsur-unsur asing ini sangat berpengaruh terhadap pemekaran kosakata bahasa Indonesia (Meysitta, 2018). Hal ini nampak pada penerbitan Kamus Besar Bahasa Indonesia (KBBI) Edisi Kelima (2016) yang resmi diluncurkan Menteri Pendidikan dan Kebudayaan pada 28 Oktober 2016. Pada edisi ini, KBBI memuat I27.036 lema yang versi cetaknya setebal 2.040 halaman, hampir dua kali lipat versi sebelumnya, I.400-an halaman (Meysitta, 2018). Dalam KBBI Edisi Kelima tersebut, I27.036 lema itu sebagiannya berasal dari 9 bahasa asing yang kosakatanya diserap ke dalam bahasa Indonesia (Meysitta, 2018; Wurianto, 2015). Kesembilan bahasa asing yang dimaksud meliputi bahasa Arab, bahasa Belanda, bahasa Inggris, bahasa Sanskerta (Jawa Kuno), bahasa Tionghoa, bahasa Portugis, bahasa Tamil, bahasa Parsi, dan bahasa Hindi (Mabruroh, 2017; Rohbiah, 2017; Sundasewu, 2015; Wurianto, 2015). Hal ini menunjukkan bahwa dalam perkembangannya bahasa Indonesia masih perlu menyerap kosakata bahasa asing seiring dengan pesatnya pengaruh global pada masyarakat Indonesia (Putro, Suryanto, \& Sumarwati, 20I5).

Eksistensi bahasa Indonesia dan kemajuan berpikir masyarakatnya di dalam memahami pengaruh global di era industri 4.0 ini tentunya harus seimbang. Pengungkap ide, pikiran, gagasan, serta perasaan penuturnya yang selalu mengikuti perkembangan zaman tidak mungkin berjalan tanpa diiringi penggunaan kata-kata yang tepat (Sakrim, 2020). Untuk itulah, penyerapan kosakata dari bahasa lainnya sangat penting dalam kehidupan ini (Putro et al., 2015). Yule berpendapat bahwa fungsi bahasa di salah satu sisi sebagai fungsi interaksi (interactional function) yakni sebagai alat untuk meningkatkan hubungan sosial (N. H. B. M. Lazim \& Jaafar, 2018; Yinghan, 2020). Bahasa Indonesia akan menunjukkan eksistensi sebagai suatu bahasa yang modern jika mampu dipakai sebagai wahana untuk mengungkapkan ide dan perasaan penuturnya (Zamrotin, 202I).

Kenyataan dalam bahasa Indonesia yang tidak dapat dihindari adalah adanya kata-kata dari bahasa asing yang diserap ke dalam bahasa Indonesia (Isnaeni, Samingin, \& Wulandari, 2020; Maneechukate, 20I4; Qashidi, 20I5). Kata-kata asing tersebut ada yang diserap secara utuh, ada pula yang mengalami modifikasi, terutama perubahan penulisan fonem vokal atau konsonan (Suharyanto, 20I5; Zamrotin, 202I). Perubahan ini tidak lepas dari usaha menyesuaikan pelafalan atau pengucapan dikarenakan bahasa Indonesia tidak memiliki kata tersebut (Fatmasari, 2020; Suharyanto, 2015). Perubahan ini juga tidak lepas dari adanya pengaruh perkembangan teknologi, perdagangan, dan komunikasi lisan antara penutur yang satu dengan lainnya (Putradi, 2016; Zamrotin, 202I). Oleh karena itu, sampai saat ini bahasa Indonesia terus berbenah diri terutama dalam hal perbendaharaan kosakatanya. Sesuai dengan ciri yang dinamis dan reseptif, bahasa Indonesia tidak dapat mengelakkan diri dari proses penyerapan unsur asing ke dalam bahasa Indonesia (Sakrim, 2020; Sundasewu, 2015). Sebagai akibatnya, cukup banyak kosakata bahasa asing, misalnya dari bahasa Belanda, bahasa Inggris, bahasa Arab, dan bahasa-bahasa asing lainnya sebagaimana di atas masuk dalam bahasa Indonesia (Mabruroh, 2017; Putro et al., 20I5; Rini, 2018; Wurianto, 2015).

Terdapat dua istilah dalam unsur serapan, yakni unsur dan serapan. Poerwadarminta menjelaskan bahwa unsur adalah bahan asal, zat asal, bagian yang terpenting dalam suatu hal, sedangkan serapan adalah pemasukan ke dalam, penyerapan masuk ke dalam lubang-lubang kecil (Maneechukate, 20I4; Qashidi, 2015). Samsuri menjelaskan serapan adalah pungutan, terkait dengan hal ini, Kridalaksana menjelaskan kata serapan adalah pinjaman baik berupa bunyi, fonem, unsur gramatikal atau unsur leksikal yang diambil dari bahasa lain (Qashidi, 20I5; Yasin, 2018). Di dalam bahasa Indonesia, kata serapan ini dapat berasal 
dari bahasa daerah dan bahasa asing. Kata serapan adalah kata yang diserap dari berbagai bahasa lain, baik dari bahasa daerah maupun dari bahasa asing, yang digunakan dalam bahasa Indonesia yang cara penulisannya mengalami perubahan ataupun tidak mengalami perubahan (Hidayah, Samingin, \& Wijayanti, 2018; Isnaeni et al., 2020).

Disadari atau tidak, penutur bahasa di Indonesia akan menggunakan kata-kata serapan baik yang berasal dari bahasa daerah maupun bahasa asing dalam peristiwa interaksi. Bahasa Indonesia sebagai sarana komunikasi dan sekaligus bagian suatu kebudayaan, tentu saja harus dipahamkan atau diajarkan baik secara langsung atau tidak ke generasi yang akan datang (Putro et al., 2015). Sebagai alat kebudayaan tertentu, bahasa itu hendaklah dapat dipakai untuk semua kehidupan di dalam kebudayaan itu (Ubaidillah, 2013). Perubahan biasa disebut sebagai pertumbuhan, seakan-akan bahasa itu merupakan sesuatu yang hidup. Bahasa hidup manapun tentu mengalami perubahan yang mungkin tidak tampak kepada pemakai-pemakai bahasa itu sendiri di dalam waktu yang pendek, tetapi secara kumulatif dan dalam waktu yang cukup lama akan terlihat dengan jelas perubahan itu (Fatmasari, 2020). Di dalam keinginannya untuk menyampaikan sesuatu, pemakai bahasa menggunakan bahasanya sebagai alat komunikasi. Untuk menghindarkan ketidakjelasan, pemakai bahasa sering secara berlebihan menyatakan isi hatinya (Sundasewu, 2015).

Terkait proses penyerapan, kata umum unsur serapan dibagi menjadi tiga, yaitu adopsi, adaptasi, dan pangutan (Meysitta, 2018). Adopsi artinya pungutan yang dilakukan secara utuh tanpa melalui perubahan dan penyesuaian, misalnya fase-fase. Adaptasi adalah penyerapan yang disesuaikan dengan kaidahkaidah bahasa Indonesia. Dalam penyesuaian kata-kata asing tersebut diusahakan tidak berbeda dengan ejaan asingnya. Perubahan hanya seperlunya saja sehingga bentuk Indonesianya masih dapat dibandingkan dengan ejaan asingnya, misalnya congress-kongres. Pungutan terjemahan merupakan pungutan yang dihasilkan dengan menerjemahkan kata/istilah tanpa mengubah makna konsep gagasan (makna konsep harus sama/sepadan) (Herniti, 2006). Bentuk terjemahan yang dihasilkan ada dua macam, yaitu (a) sama, misalnya batasan - definisi dan (b) tidak sama, misalnya makalah - working paper.

Terdapat enam faktor yang memengaruhi penyerapan yang terjadi di masyarakat yang meliputi (I) prinsip kehematan, (2) kejarangan bentuk asli, (3) keperluan akan kata yang searti, (4) pembedaan arti di dalam bahasa sendiri yang kurang cermat, (5) gengsi bahasa asing, dan (6) kemampuan berbahasa penutur yang rendah (Herniti, 2006; Meysitta, 2018). Prinsip kehematan merupakan contoh usaha mencari kata-kata serapan karena kata-kata yang diserap lebih hemat dibandingkan dengan kata bahasa Indonesia. Memilih kata-kata dari bahasa asing yang sudah siap pakai dan tidak boros atau bertele-tele merupakan cara yang hemat jika dibandingkan dengan memerikan konsep dalam bahasa Indonesia, misalnya fonologi, antropologi, linguistik, dan masih banyak yang lainnya (Herniti, 2006; Meysitta, 2018; Putradi, 2016; Suharyanto, 2015). Kejarangan bentuk asli juga menjadi faktor penyebab diserapnya katakata atau unsur asing ke dalam bahasa Indonesia. Unsur leksikal asli yang jarang digunakan tidak termasuk kosakata produktif penutur bahasa jika ia bukan ahli bahasa. Kata dursila, misalnya, berpadanan dengan evil atau immoral. Namun, karena kata Melayu itu frekuensi pemakaiannya sangat rendah, terciptalah bentuk asusila berdasarkan analogi yang salah, yakni moral:amoral, susila:asusila dengan menyamakan arti amoral dengan immoral.

Pertimbangan kelanggaman (stilistik) dapat mendorong penutur bahasa mencari sinonim demi variasi estetik di dalam ujaran dan tulisannya (Sakrim, 2020). Pemahaman bahasa lain memberinya peluang menyerap unsur kosakata bahasa itu, lepas dari masalah perlu tidaknya dilakukan penyerapan itu jika di dalam bahasanya sendiri terhadap sinonim yang memadai, misalnya asimilasi dan pembauran, penyerapan; kontrol dan pengawasan, pengendalian, penilikan; spesial dan khusus; fasilitas dan kemudahan (Fatmasari, 2020; Zamrotin, 202I). Kadang-kadang timbul perasaan pada penutur bahasa bahwa bahasanya tidak memiliki peranti untuk membedakan dengan cermat berbagai konsep yang bertalian, benar tidaknya anggapannya itu tidak disadarinya. Oleh karena itu, perlu menularkan perbedaan bentuk di dalam bahasa asing ke dalam bahasanya sendiri dengan menyerap seperangkat kata yang termasuk dalam satu paradigma, misalnya politik dan politis, universitas dan universiter, norma dan

Gigit Mujianto, Sudjalil, Tipe modifikasi fonem kata serapan asing ke dalam bahasa Indonesia pada surat kabar online berbahasa Indonesia 
normatif. Kefasihan berbahasa asing, khususnya bahasa yang ditautkan dengan peradaban yang tinggi, kadang-kadang disangka penutur bahasa akan meningkatkan kedudukan sosialnya di mata orang (Herniti, 2006; Meysitta, 2018). Oleh karena itu, diseraplah evaluasi, bilateral, multiplikasi, dan kalibrasi walaupun ada bentuk penilaian, dwipihak, pelipatan dan kelipatan, serta peneraan. Penutur bahasa di antara kalangan elite sosial tidak sedikit yang kosakata asingnya lebih luas cakupannya daripada kosakata Indonesia ragam tingginya, dan taraf pemahaman kaidah gramatikal bahasa asing lebih tinggi daripada taraf pemahamannya di bidang bahasa Indonesia (Herniti, 2006; Meysitta, 2018). Pada proses pengalimatan buah pikirannya lalu mungkin terjadi interferensi pola struktur kalimat asing yang mendorongnya menciptakan serapan terjemah. Di dalam beberapa ragam, misalnya, dapat ditemukan unsur serapan dalam mana, atas mana, untuk mana, kepada siapa, dan dengan siapa sebagai konjungsi, yang masing-masing berpola pada waarin/in which, waarop/wherefore, waarvoor/wherefore dan aanwiel/to whom, dan met wie/with whom.

Adanya penyerapan kata-kata asing ini tidak dapat dihindari karena bahasa Indonesia mengalami kemajuan yang pesat, terutama dalam penambahan kosakata (Herniti, 2006; Meysitta, 2018). Salah satu proses penyerapan yang dilakukan secara besar-besaran terjadi pada surat kabar online. Surat kabar online sebagai salah satu media massa, yang kehadirannya di tengah-tengah masyarakat sangatlah penting. Fungsi utama media ini adalah sebagai penyampai informasi kepada masyarakat. Kelebihan surat kabar online adalah menyampaikan informasi kepada masyarakat, di sisi lain harganya yang relatif murah, beritanya menyeluruh, jangkauannya luas mencakup masyarakat di berbagai tempat dalam waktu yang bersamaan (Setianingrum \& Hidayat, 2019; Sudjalil, 2018). Selain itu, fungsi surat kabar online sebagai penyampaian informasi tidak hanya berdampak pada perkembangan informasi yang dimiliki masyarakat yang membacanya, tetapi dapat menyebar lebih luas kepada masyarakat yang tidak membaca surat kabar online tersebut. Keberadaan surat kabar online banyak diminati oleh masyarakat, karena dapat dibaca di berbagai tempat. Walaupun di zaman sekarang sudah ada media elektronik lain yang lebih canggih dalam penyampaian informasi yang lebih cepat dan teraktual (Arifin, Wibawa, \& Syahrial, 20I9; Setianingrum \& Hidayat, 2019). Selain itu, keberadaan surat kabar online sebagai sarana kontrol dan pendidikan dalam menyebarkan informasi yang relevan untuk dikonsumsi masyarakat pembaca. Kondisi tersebut menunjukkan bahwa surat kabar online tidak lepas dari aspek-aspek bagaimana cara tulisan jurnalistik dalam menyampaikan informasi yang tulus kepada khalayak (Arifin et al., 2019; Setianingrum \& Hidayat, 2019).

Dengan demikian, eksistensi sebuah surat kabar online merupakan hal yang sangat penting untuk dipertahankan. Keajegan penerbitannya merupakan salah satu wujud kekonsistenan dalam menyampaikan informasi yang bermutu untuk masyarakat (Arifin et al., 2019; Setianingrum \& Hidayat, 2019). Hal ini dapat dilihat dari semua surat kabar yang memiliki kekhasan sendiri dalam menyampaikan informasi untuk khalayak pembaca, misalnya jawapos.com. Seperti halnya pertumbuhan surat kabar di Indonesia, jawapos.com secara kualitasnya dalam mendapatkan, mengolah dan menyebarkan informasi untuk masyarakat dapat diterima secara mudah oleh khalayak. Selain mengacu pada ciri-ciri bahasa jurnalistik yang baik dan selalu memperhatikan prinsip-prinsip penggunaan bahasa Indonesia secara benar, surat kabar online jawa pos.com membuat standar yang berlaku di lingkungan internalnya. Tujuannya, untuk membentuk identitas gaya penampilan, serta menjembatani kepentingan bahasa yang benar dan bahasa yang baik. Selain itu, untuk merumuskan kesepakatan tentang penulisan kata, istilah, singkatan, akronim, yang belum termuat di kamus atau yang belum ada aturannya yang baku, dan untuk mengingatkan wartawan atau karyawannya tentang penulisan kata serapan atau istilah asing yang sering salah kaprah yang harus dihindari (Herniti, 2006; Meysitta, 2018; Yasin, 2018). Selain mengacu pada penulisan kata serapan atau istilah yang benar menurut kamus bahasa Indonesia, penulisan kata serapan sangat mungkin diketahui tipe penulisan fonemnya (Meysitta, 2018; Sakrim, 2020; Young \& Rusli, 2019).

Meskipun demikian, harus diakui bahwa dalam era globalisasi ini semakin lama semakin tergeser keberadaan surat kabar dengan media elektronik seperti TV dan sebagainya, meskipun ada sebagian masyarakat yang masih setia untuk mendapatkan informasi dari media surat kabar. Dengan begitu 
pesatnya perkembangan media surat kabar online, tidak menuntut kemungkinan hanyalah sedikit masyarakat yang setia untuk mengonsumsi surat kabar sebagai informasi yang bermutu, apalagi di kalangan mahasiswa yang seharusnya surat kabar sebagai kebutuhan konsumsi setiap hari dalam mencari informasi (Arifin et al., 2019). Oleh karena itu, surat kabar online merupakan kumpulan berita atau informasi yang terjadi dalam kehidupan sehari-hari.

Selain memuat informasi penting, surat kabar online merupakan wahana inovasi perkembangan bahasa Indonesia terutama penggunaan kata serapan asing (Herniti, 2006). Tidak sedikit kata-kata asing terdapat dalam surat kabar, karena cukupnya kosakata bahasa Indonesia di dalam memuat gagasan penulisnya (Herniti, 2006; Meysitta, 2018; Suartini, 2010). Tentu saja hal ini sangat diwarnai oleh kompetensi wartawannya di dalam memasukkan atau menggunakan kata-kata tersebut. Surat kabar sebagai media online selain berguna bagi masyarakat pada umumnya juga sangat penting bagi mahasiswa. Dapat dikatakan bahwa pentingnya surat kabar untuk mahasiswa karena surat kabar merupakan sumber informasi yang cukup penting dan akurat yang berisikan apa saja yang terjadi dalam aspek politik, kebudayaan, agama dan pendidikan sebagai landasan pengetahuan dan sebagainya (Arifin et al., 2019). Untuk memahami gagasan, konsep, serta berbagai informasi di dalam surat kabar, mahasiswa tentunya harus mampu menguasai bahasa Indonesia secara baik pula (Meysitta, 2018; Setianingrum \& Hidayat, 2019).

Sering digunakannya kata serapan asing ke dalam bahasa Indonesia sebagaimana dalam surat kabar berbahasa Indonesia, akan berdampak pada pemekaran kosakata bahasa Indonesia. Terkait dengan pemerkayaan kosakata bahasa Indonesia, penelitian mengenai tipe modifikasi fonem kata serapan asing ke dalam bahasa Indonesia pada surat kabar berbahasa Indonesia jawapos.com perlu dilakukan untuk menemukan perubahan struktur fonem pada kata serapan asing. Hal inilah yang menjadikan pembeda penelitian ini dengan beberapa penelitian terdahulu yang telah dilakukan. Adapun penelitian terdahulu yang sudah dilakukan lebih banyak membahas mengenai perubahan fonem seperti yang dilakukan oleh (Cooke, Aubanel, \& García Lecumberri, 2019; Fatmasari, 2020; Galovic, 2017; Gjerga, Dugourd, Tobalina, Sousa, \& Saez-Rodriguez, 202I; Huilgol, Baik, \& Shattuck-Hufnagel, 20I9; Khonglah, Dey, \& Prasanna, 2019; N. H. B. M. Lazim \& Jaafar, 20I8; N. H. M. Lazim \& Jaafar, 20I8; Putradi, 20I6; Rafalko, 2018; Sakrim, 2020; Sudro \& Prasanna, 202I; Suharyanto, 2015; Sundasewu, 20I5; Valipur, 2018; Zamrotin, 202I). Beberapa penelitian lain lebih banyak membahas mengenai kata serapan bahasa asing ke dalam bahasa Indonesia seperti yang dilakukan oleh (Hidayah et al., 2018; Isnaeni et al., 2020; N. H. B. M. Lazim \& Jaafar, 2018; Mabruroh, 2017; Maneechukate, 20I4; Putro et al., 2015; Qashidi, 2015; Rini, 2018; Rohbiah, 2017; Suartini, 2010; Ubaidillah, 2013; Wurianto, 2015; Yasin, 2018; Yinghan, 2020). Sepengetahuan penulis belum ada penelitian tentang tipe modifikasi fonem kata serapan asing ke dalam bahasa Indonesia pada surat kabar online berbahasa Indonesia, sehingga penelitian ini berbeda dengan penelitian terdahulu yang telah dilakukan. Penelitian ini bertujuan untuk mendeskripsikan tipe modifikasi fonem kata serapan asing ke dalam bahasa Indonesia pada surat kabar online berbahasa Indonesia. Secara umum hasil penelitian ini dapat digunakan sebagai bahan untuk melihat perubahan yang terjadi dalam proses penyerapan kata-kata asing ke dalam bahasa Indonesia, terutama terkait dengan bidang fonologi, yaitu perubahan fonem vokal dan fonem konsonan. Hal ini penting karena perubahan fonem vokal dan konsonan merupakan langkah awal untuk menyesuaikan pelafalan kata asing tersebut ke dalam bahasa Indonesia sebelum kata-kata tersebut dipopulerkan kepada masyarakat.

\section{METODE}

Penelitian ini merupakan penelitian deskripsi tentang tipe modifikasi fonem pada kata serapan asing ke dalam bahasa Indonesia dalam surat kabar Jawa Pos online edisi Maret 2020. Pendekatan yang digunakan dalam penelitian ini adalah pendekatan kualitatif dengan model analisis morfologis. Metode penelitian mengenai tipe modifikasi fonem pada kata serapan asing ke dalam bahasa Indonesia dalam surat kabar Jawa Pos online edisi Maret 2020 adalah metode kualitatif. Penelitian kualitatif sebagai suatu tradisi dalam ilmu-ilmu sosial secara fundamental bergantung pada pengamatan langsung atas manusia di

Gigit Mujianto, Sudjalil, Tipe modifikasi fonem kata serapan asing ke dalam bahasa Indonesia pada surat kabar online 
lingkungan hidup mereka yang nyata. Adapun lima ciri karakteristik penelitian kualitatif antara lain; (I) natural setting sebagai sumber langsung dan peneliti sebagai instrumen kunci; (2) bersifat deskriptif; (3) lebih mengutamakan proses dari pada hasil; (4) analisis data secara induktif; dan (5) makna atau meaning sebagai perhatian utamanya. Data dalam penelitian ini adalah berupa kata serapan asing ke dalam bahasa Indonesia yang terdapat dalam surat kabar Jawa Pos online edisi Maret 2020. Bentuk data adalah kata serapan asing yang mengalami penyesuaian. Sumber data yang digunakan oleh peneliti dalam melakukan penelitian ini adalah kata-kata asing yang terdapat dalam surat kabar Jawa Pos online edisi Maret 2020 pada rubrik sport, informasi, bisnis, ekonomi, politik, dan fashion, yang meliputi tipe modifikasi fonem kata serapan asing ke dalam bahasa Indonesia.

Untuk memperoleh data, maka peneliti melakukan pengumpulan data dengan menggunakan teknik observasi dan teknik dokumenter. Teknik observasi ini dilakukan untuk mengumpulkan data penelitian berupa kata serapan asing dalam surat kabar Jawa Pos online edisi Maret 2020. Adapun teknik dokumenter dilakukan untuk mengumpulkan data kata serapan asing pada surat kabar Jawa Pos online edisi Maret 2020. Keseluruhan data potensial yang telah dikumpulkan, kemudian diseleksi lagi oleh peneliti sehingga dapat diidentifikasi data-data yang relevan dengan tujuan penelitian dan yang tidak. Penyeleksian data dilakukan atas dasar landasan konseptual penelitian, permasalahan penelitian, alasan-alasan, dan instrumen penelitian. Data-data yang relevan saja yang kemudian dipaparkan dalam penelitian ini, untuk mendapatkan temuan-temuan penelitian. Penyeleksian data dilakukan secara berurutan mulai dari bentuk, bahasa sumber, dan proses modifikasi fonem, dan tipe modifikasi fonem dalam surat kabar Jawa Pos online edisi Maret 2020.

Data yang telah diseleksi kemudian diorganisasikan dengan cara mengurutkan, mengelompokkan, memberi kode, dan mengategorikan melalui teknik (I) analisis kata serapan asing dan (2) analisis modifikasi kata serapan asing. Secara umum teknik analisis data yang digunakan dalam penelitian ini adalah teknik model analisis Miles dan Hubermen disebut model interaktif (Miles \& Huberman, 1994).

\section{HASIL DAN PEMBAHASAN}

Istilah tipe dalam penelitian ini diartikan model atau pola perubahan fonem pada kata serapan asing (bahasa Inggris, bahasa Belanda, dan bahasa Arab). Pola perubahan fonem kata didasarkan pada pedoman pembentukan istilah khususnya pada penyerapan unsur asing. Pedoman ini selanjutnya digunakan untuk menganalisis kevariasian perubahan fonem kata asing ke dalam bahasa Indonesia. Terdapat 8 tipe modifikasi fonem pada kata serapan bahasa asing ke dalam bahasa Indonesia yang telah ditemukan dalam penelitian, yakni (I) tipe tanpa penyesuaian ejaan (TTPE), (2) tipe penyesuaian ejaan (TPE), (3) tipe penyesuaian gugus fonem (TPGF), (4) tipe penyesuaian sufiks asing (TPSA), (5) tipe jejeran konsonan atau vokal kembar (TJKVK), (6) tipe gabung I (penggabungan TPE dan TPGF), (7) tipe gabung II (penggabungan TPE dan TPSA), dan (8) tipe gabung III (penggabungan TPGF dan TJKVK). Adapun ulasan lengkap mengenai tipe modifikasi fonem pada kata serapan asing ke dalam bahasa Indonesia sebagai berikut ini.

\section{Tipe I: Tipe Tanpa Penyesuaian Ejaan (TTPE)}

Tabel I

Tipe Tanpa Penyesuaian Ejaan (TTPE)

\begin{tabular}{cl} 
No & \multicolumn{1}{c}{ Data } \\
\hline I & total \\
2 & plus \\
3 & bank \\
4 & modern \\
5 & supermarket \\
6 & retail \\
7 & kamis \\
8 & khidmat \\
9 & aroma \\
\hline
\end{tabular}


Tipe tanpa penyesuaian ejaan diartikan penyerapan unsur asing tanpa dilakukan penyesuaian ejaan dan lafal. Kata-kata asing yang masuk ke dalam bahasa Indonesia dan digunakan oleh penuturnya diserap secara utuh. Hal ini banyak terjadi di bahasa Indonesia baik dari bahasa Inggris, bahasa Belanda, dan bahasa Arab. Proses penyerapan istilah asing, dengan mengutamakan bentuk visualnya, dilakukan dengan cara yang berikut: (I) penyerapan dengan penyesuaian ejaan dan lafal, (2) penyerapan dengan penyesuaian ejaan tanpa penyesuaian lafal, (3) penyerapan tanpa penyesuaian ejaan, tetapi dengan penyesuaian lafal, (4) penyerapan tanpa penyesuaian ejaan dan lafal, dan (5) penyerapan istilah penyesuaian ejaan dan lafal dilakukan jika istilah itu juga dipakai secara luas dalam kosakata umum, istilah itu tidak ditulis dengan huruf miring (dicetak dengan huruf tegak).

Kata-kata serapan asing yang berbentuk dasar tanpa penyesuaian ejaan yang ditemukan dalam penelitian ini berasal dari bahasa Inggris dan Belanda seperti pada Tabel I. Kesembilan kata serapan diserap secara utuh ke dalam bahasa Indonesia. Kutipan kalimat untuk kata-kata ini telah dipaparkan pada halaman sebelumnya. Struktur kata yang tergolong tipe I ini berbentuk (I) monomorfemis, (2) monosilabis, dan (3) polisilabis. Penyerapan kata atau istilah ini dilakukan tanpa penyesuaian ejaan dan lafal. Kata-kata tersebut benar-benar diserap secara utuh tanpa dilakukan modifikasi fonem.

Temuan penelitian ini serupa dengan penelitian yang dilakukan oleh (Isnaeni et al., 2020; Putradi, 2016) yang menyimpulkan bahwa sejumlah kata serapan asing yang telah diadopsi ke dalam bahasa Indonesia masih banyak yang menyesuaikan dengan bentuk dasar tanpa harus menyesuaikan dengan ejaan. Terkait dengan temuan tipe proses modifikasi kata serapan dalam bahasa Indonesia, (IInran, 2005; Nafisah, 2017) mengatakan bahwa kata serapan dapat diserap secara utuh, apabila bilingual pembawa kata serapan menguasai bahasa itu secara baik.

\section{Tipe 2: Tipe Penyesuaian Ejaan (TPE)}

Tabel 2

\begin{tabular}{|c|c|}
\hline \multicolumn{2}{|c|}{ Tipe Penyesuaian Ejaan (TPE) } \\
\hline No & Data \\
\hline $\mathrm{I}$ & sentral $\longleftarrow$ central \\
\hline 2 & ekonomi economy \\
\hline 3 & seluler $\leftarrow$ celuler \\
\hline 4 & simbiosis $\longleftarrow$ symbiosis \\
\hline 5 & 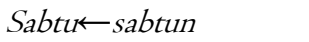 \\
\hline 6 & Kamis $\leftarrow$ khamiis (arab) \\
\hline 7 & rezeki $\leftarrow r i z q i$ \\
\hline 8 & lokak local \\
\hline 9 & fisik $\leftarrow$ fysiek \\
\hline 10 & ilegak $\leftarrow$ illegal \\
\hline II & ekosistem ecosystem \\
\hline $\mathrm{I} 2$ & sosiak social \\
\hline
\end{tabular}

Penyesuaian ejaan yang dimaksudkan pada tipe 2 ini adalah terjadinya modifikasi konsonan atau vokal baik pada posisi awal, tengah, maupun akhir kata. Tipe 2 ini juga banyak ditemukan dalam penelitian ini. Kata-kata yang bertipe 2 ini ditandai adanya modifikasi fonem serapan, vokal /-e/ pada suku kata akhir menjadi / $\varnothing /$, konsonan /-t-/ di tengah kata menjadi /-s-/, konsonan /c-/ di awal kata menjadi /k-/, konsonan / c-/ di awal kata menjadi /s-/, dan konsonan /-y/ di akhir kata menjadi /-i/. Kata-kata serapan yang ditemukan dalam penelitian ini seperti pada Tabel 2. Masing-masing kata yang telah dilakukan penyesuaian dipaparkan sebagai berikut ini.

Data I berupa kata sentral mengalami proses penyesuaian ejaan dalam bahasa Indonesia. Kata sentral ini berasal dari bahasa Inggris central dan kata ini akan mengalami penyesuaian ejaan, yakni dari $-c$ menjadi $-s$. 
Data 2 berupa kata ekonomi ini berasal dari bahasa Inggris economy yang mengalami penyesuaian ejaan dalam bahasa Indonesia, yakni dari $-c$ menjadi $-k$, dan penyesuaian ejaan dalam bahasa Indonesia, yakni dari $-y$ menjadi $-i$.

Data 3 berupa kata seluler ini berasal dari kata dalam bahasa Inggris celuler yang mengalami penyesuaian ejaan dalam bahasa Indonesia, yakni dari $-c$ menjadi $-s$.

Data 4 berupa kata simbiosis mengalami proses penyesuaian ejaan dalam bahasa Indonesia. Kata simbiosis ini berasal dari bahasa Inggris symbiosis dan kata ini akan mengalami penyesuaian ejaan, yakni dari $-y$ menjadi $-i$.

Data 5 berupa kata sabtun mengalami proses penyesuaian ejaan dalam bahasa. Kata sabtu ini berasal dari kata dalam bahasa Arabsabtun yang mengalami penyesuaian ejaan dalam bahasa Indonesia, yakni dengan cara menanggalkan huruf -n.

Data 6 berupa kata kamiis mengalami proses penyesuaian ejaan dalam bahasa. Kata kamis ini berasal dari kata dalam bahasa Arab kamiis yang mengalami penyesuaian ejaan dalam bahasa Indonesia, yakni dengan cara menambahkan huruf $-i$.

Data 7 berupa kata rizqi mengalami proses penyesuaian ejaan dalam bahasa. Kata rezeki ini berasal dari kata dalam bahasa Arab rizqi yang mengalami penyesuaian ejaan dalam bahasa Indonesia, yakni dengan cara menyesuaikan huruf $-\mathrm{q}$ menjadi $-\mathrm{k}$.

Selain itu, dipaparkan kata-kata yang tergolong tipe 2 sebagai berikut ini. Data 8 berupa kata local mengalami proses penyesuaian ejaan dalam bahasa Indonesia. Kata lokal ini berasal dari bahasa Inggris local dan kata ini akan mengalami penyesuaian ejaan, yakni dari $-c$ menjadi $-k$.

Data 9 berupa kata fysiek mengalami proses penyesuaian ejaan dalam bahasa Indonesia. Kata fisik ini berasal dari kata dalam bahasa Belanda fysiek yang mengalami penyesuaian ejaan dalam bahasa Indonesia, yakni dari $-y$ menjadi $-i$, dan $-i e$ menjadi $-i$, kata ini diserap secara utuh dari bahasa Arab dan tidak mengalami penyesuaian ejaan dalam bahasa Indonesia.

Data 10 berupa kata illegal ini berasal dari kata dalam bahasa Inggris illegal yang mengalami penyesuaian ejaan dalam bahasa Indonesia, yakni dari -11 menjadi -1 . Konsonan kembar menjadi satu huruf konsonan kecuali jika terdapat pasangan yang dapat menimbulkan kekeliruan makna.

Data II berupa kata ekosistem ini berasal dari bahasa Inggris ecosystem dan kata ini akan mengalami penyesuaian ejaan, yakni dari $-c$ menjadi $-s$ dan dari $-y$ menjadi $-i$.

Data $\mathrm{I} 2$ berupa kata socialmengalami proses penyesuaian ejaan dalam bahasa Indonesia. Kata sosial ini berasal dari bahasa Inggris social dan kata ini akan mengalami penyesuaian ejaan, yakni dari $-c$ menjadi $-s$.

Temuan penelitian ini serupa dengan penelitian yang dilakukan oleh (Hidayah et al., 2018; Sundasewu, 2015) yang menyimpulkan bahwa beberapa kata serapan asing telah terjadi modifikasi konsonan atau vokal baik pada posisi awal, tengah, maupun akhir kata ke dalam bahasa Indonesia. Terkait dengan temuan tipe proses modifikasi kata serapan dalam bahasa Indonesia, (IInran, 2005; Nafisah, 2017) mengatakan bahwa kata serapan yang telah dilakukan berada dalam kondisi bilingual pembawa kata serapan sangat rendah penguasaan terhadap bahasa asingnya, maka akan terjadi penyelarasan secara fonologis, morfologis, leksikal, dan sintaksis ke dalam bahasa penerima. 


\section{Tipe 3: Tipe Penyesuaian Gugus Fonem (TPGF)}

Tabel 3

\begin{tabular}{|c|c|}
\hline \multicolumn{2}{|c|}{ Tipe Penyesuaian Gugus Fonem (TPGF } \\
\hline No & Data \\
\hline $\mathrm{I}$ & 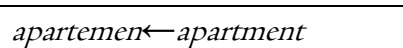 \\
\hline 2 & mal $\leftarrow$ mallinvestor $\leftarrow$ investors \\
\hline 3 & produk $\leftarrow$ product \\
\hline 4 & standar $\leftarrow$ standard \\
\hline 5 & ilegak illegal \\
\hline 6 & foto $\leftarrow$ photo \\
\hline 7 & simpek simple \\
\hline 8 & klub $\leftarrow$ club \\
\hline 9 & tes $\longleftarrow$ test \\
\hline I0 & staf $\leftarrow$ staff \\
\hline II & stok $\longleftarrow$ stock \\
\hline $\mathrm{I} 2$ & stiker $\longleftarrow$ sticker \\
\hline
\end{tabular}

Penyesuaian gugus konsonan asing yang dimaksudkan pada tipe 3 ini adalah terjadinya modifikasi jejeran dua konsonan atau lebih yang berposisi pada awal, tengah, maupun akhir kata. Gugus konsonan ialah jajaran dua konsonan atau lebih yang merupakan satu kesatuan bunyi. Gugus konsonan terdapat hanya pada satu suku kata. Hal ini perlu dibedakan antara gugus konsonan dengan deret konsonan. Kalau deret konsonan tiap fonemnya menjadi anggota dari suku kata yang berlainan, sedangkan pada gugus konsonan seluruh jajaran konsonannya terdapat dalam satu suku kata (silabe). Distribusi gugus konsonan ini ada yang menduduki pada posisi awal, tengah, dan akhir suku kata. Kata serapan yang tergolong pada tipe 3 ini sebagaimana pada Tabel 3. Untuk memperjelas pemahaman proses modifikasi kata-kata serapan yang berasal dari kata asing bergugus konsonan sebagai berikut ini.

Data I berupa kata apartemen termasuk kategori kata nomina dan tidak mengalami perubahan kategori kata. Kata apartemen mengalami proses penyesuaian gugus konsonan di akhir kata. Kata apartemen ini berasal dari kata dalam bahasa Inggris bergugus konsonan di akhir yang diserap ke dalam bahasa Indonesia dan kata ini akan mengalami penyesuaian ejaan, yakni dari $-n t$ menjadi $-n$.

Data 2 berupa kata mal termasuk kategori kata nomina dan tidak mengalami perubahan kategori kata. Kata mal termasuk kata yang memiliki gugus konsonan yakni -1l. Kata ini mengalami proses penyesuaian ejaan dalam bahasa Indonesia. Kata ini diserap dari kata bahasa Inggris. Konsonan kembar pada mall dalam bahasa Inggris akan menjadi satu huruf konsonan dalam bahasa Indonesia sehingga menjadi mal. Data 2 berupa kata investor termasuk kategori kata nomina dan tidak mengalami perubahan kategori kata. Kata investor mengalami proses penyesuaian gugus konsonan di akhir kata. Kata investor ini berasal dari kata dalam bahasa Inggris bergugus konsonan di akhir yang diserap ke dalam bahasa Indonesia dan kata ini akan mengalami penyesuaian ejaan, yakni dari $-t s$ menjadi $-s$.

Data 3 berupa kata produk termasuk kategori kata nomina dan tidak mengalami perubahan kategori kata. Kata product mengalami proses penyesuaian gugus konsonan di akhir kata. Kata produk ini berasal dari kata dalam bahasa Inggris bergugus konsonan di akhir yang diserap ke dalam bahasa Indonesia dan kata ini akan mengalami penyesuaian ejaan, yakni dari $-c s$ menjadi $-k$.

Data 4 berupa kata standar termasuk kategori kata nomina dan tidak mengalami perubahan kategori kata. Kata standar mengalami proses penyesuaian gugus konsonan di akhir kata. Kata standard ini berasal dari kata dalam bahasa Inggris bergugus konsonan di akhir yang diserap ke dalam bahasa Indonesia dan kata ini akan mengalami penyesuaian ejaan, yakni dari $-r d$ menjadi $-r$.

Data 5 berupa kata ilegal termasuk kategori kata adverbia dan tidak mengalami perubahan kategori kata. Kata illegal mengalami proses penyesuaian ejaan dalam bahasa Indonesia. Kata illegal ini berasal dari kata dalam bahasa Inggris illegal yang mengalami penyesuaian ejaan dalam bahasa Indonesia, yakni dari -11 menjadi $-l$. Konsonan kembar menjadi satu huruf konsonan kecuali jika terdapat pasangan yang dapat menimbulkan kekeliruan makna.

Gigit Mujianto, Sudjalil, Tipe modifikasi fonem kata serapan asing ke dalam bahasa Indonesia pada surat kabar online 
Data 6 berupa kata foto termasuk kategori kata nomina dan tidak mengalami perubahan kategori kata. Kata photo mengalami proses penyesuaian ejaan dalam bahasa Indonesia. Kata foto ini berasal dari bahasa Inggris photo dan kata ini akan mengalami penyesuaian ejaan, yakni dari ph-menjadi $-f$.

Data 7 berupa kata simpel termasuk kategori kata adverbia dan tidak mengalami perubahan kategori kata. Kata simpel diserap dari kata bahasa Inggris simple. Kata simple termasuk kata yang memiliki gugus konsonan (kluster) di tengah kata yakni ple-. Kata ini mengalami proses penyesuaian ejaan dalam bahasa Indonesia menjadi - pel. Kata ini diserap secara utuh dari kata bahasa Inggris.

Data 8 berupa kata klub termasuk kategori kata nomina dan tidak mengalami perubahan kategori kata. Kata klub termasuk kata yang memiliki gugus konsonan (kluster) di awal kata yakni kl-. Kata ini telah mengalami proses penyesuaian ejaan dalam bahasa Indonesia yakni cl- menjadi kl-. Kata ini diserap secara utuh dari kata bahasa Inggris.

Data 9 berupa kata tes termasuk kategori kata nomina dan tidak mengalami perubahan kategori kata. Kata tes berasal dari kata test dari bahasa Inggris dan mengalami proses penyesuaian ejaan dalam bahasa Indonesia. Kata tes diserap dari kata bahasa Inggris test. Kata test ini memiliki gugus konsonan (kluster) pada akhir kata dan mengalami penyesuaian ejaan dalam dalam bahasa Indonesia dari -st menjadi $-s$. Penulisan kata tes sudah sesuai dengan Pedoman Umum Ejaan Bahasa Indonesia dan Pedoman Pembentukan Istilah.

Data 10 berupa kata staf termasuk kategori kata nomina dan tidak mengalami perubahan kategori kata. Kata staff dalam bahasa Inggris termasuk kata yang memiliki gugus konsonan yakni $-f f$. Kata ini mengalami proses penyesuaian ejaan dalam bahasa Indonesia. Kata staf ini diserap dari kata bahasa Inggris. Konsonan kembar pada staff dalam bahasa Inggris akan menjadi satu huruf konsonan dalam bahasa Indonesia sehingga menjadi staf.

Data II berupa kata stok termasuk kategori kata nomina dan tidak mengalami perubahan kategori kata. Kata stok berasal dari kata stock dari bahasa Inggris dan mengalami proses penyesuaian ejaan dalam bahasa Indonesia. Kata stok diserap dari kata bahasa Inggris stock. Kata stock ini memiliki gugus konsonan (kluster) pada akhir kata dan mengalami penyesuaian ejaan dalam bahasa Indonesia dari $-c k$ menjadi $-k$.

Data 12 berupa kata stiker termasuk kategori kata nomina dan tidak mengalami perubahan kategori kata. Kata stiker berasal dari kata sticker dari bahasa Belanda dan mengalami proses penyesuaian ejaan dalam bahasa Indonesia. Kata stiker diserap dari kata bahasa Belanda yakni sticker. Kata sticker ini memiliki gugus konsonan (kluster) pada akhir kata dan mengalami penyesuaian ejaan dalam dalam bahasa Indonesia dari - $c k$ menjadi $-k$. Penulisan kata stiker sudah sesuai dengan Pedoman Umum Ejaan Bahasa Indonesia dan Pedoman Pembentukan Istilah.

Kata serapan yang mengalami penyesuaian pada gugus konsonan asing tersebut secara konsisten mengalami modifikasi yang berpola. Tuntutan kemudahan pelafalan dan penulisan dalam bahasa Indonesia diperlukan agar ide, gagasan, perasaan, atau maksud penuturnya dapat diterima secara jelas. Hal ini sebagai bukti bahwa bahasa Indonesia secara periodik agar menyerap unsur asing guna memenuhi kebutuhan pemahaman aspek kebahasaan yang ada. Sebaliknya deret fonem atau jejeran dua vokal/konsonan yang masing-masing vokal atau konsonan tersebut berada pada suku kata yang berbeda tidak ditemukan dalam penelitian ini. Deret konsonan atau vokal, kedudukannya secara berurutan dan bersifat silabis, karena masing-masing konsonan atau vokal berurutan tersebut merupakan anggota dari suku kata yang berlainan dan pelafalannya mendapat tekanan/hembusan nafas yang sama atau hampir sama. Deret konsonan atau vokal ini posisinya terdapat di akhir suku kata, sedangkan konsonan kedua terdapat di awal suku kata.

Temuan penelitian ini serupa dengan penelitian yang dilakukan oleh (Herniti, 2006; Hidayah et al., 2018; Sundasewu, 2015) yang menyimpulkan bahwa beberapa kata serapan asing telah mengalami penyesuaian gugus konsonan asing yang dimaksudkan pada tipe 3 ini adalah terjadinya modifikasi jejeran dua konsonan atau lebih yang berposisi pada awal, tengah, maupun akhir kata. Terkait dengan temuan tipe proses modifikasi kata serapan ke dalam bahasa Indonesia, (IInran, 2005; Nafisah, 20I7) 
mengatakan bahwa kata serapan yang telah dilakukan berada dalam kondisi bilingual pembawa kata serapan sangat rendah penguasaan terhadap bahasa asingnya, maka akan terjadi penyelarasan secara fonologis, morfologis, leksikal, dan sintaksis ke dalam bahasa penerima.

\section{Tipe 4: Tipe Penyesuaian Sufiks Asing (TPSA)}

Tabel 4

\begin{tabular}{|c|c|}
\hline \multicolumn{2}{|c|}{ Tipe Penyesuaian Sufiks Asing (TPSA) } \\
\hline No & Data \\
\hline $\mathrm{I}$ & didominasi $\leftarrow$ domination \\
\hline 2 & logistik logistics \\
\hline 3 & investasi $\leftarrow$ investation \\
\hline 4 & simbiosis $\leftarrow$ symbiosis \\
\hline 5 & sensasi $\leftarrow$ sensation \\
\hline 6 & informasi $\leftarrow$ information \\
\hline 7 & potensi $\leftarrow$ potency \\
\hline 8 & divisi $\leftarrow$ division \\
\hline
\end{tabular}

Sufiks merupakan imbuhan akhir pada bentuk dasar. Sufiks dalam bahasa Inggris atau bahasa asing lainnya tentu saja berbeda. Setiap bahasa yang bertipologi aglutinatif akan membentuk kata dasarnya menjadi kata bentukan. Proses pembentukan kata dasar ini akan berdampak pada berubahnya kelas kata atau tidak. Akan tetapi, afiksasi melalui sufiks ini jelas akan mengubah makna kata tersebut. Proses modifikasi fonem yang berasal dari sufiks asing ini berbeda dengan sufiks internal dalam suatu bahasa. Modifikasi sufiks asing yang berasal dari bahasa Inggris ke bahasa Indonesia tidak mengubah kelas kata atau maknanya. Modifikasi ini dilakukan dalam rangka memudahkan penulisan dan pelafalan dalam bahasa aseptor, dalam hal ini adalah bahasa Indonesia. Kata-kata bahasa Inggris yang bersufiks dan mengalami penyesuaian dalam bahasa Indonesia yang ditemukan dalam penelitian ini sebagaimana pada Tabel 4. Untuk memperjelas pemahaman proses modifikasi kata-kata serapan yang berasal dari kata asing bersufiks asing sebagai berikut ini dipaparkan proses modifikasi kata yang sebagaimana berikut.

Data I berupa kata dominasi termasuk kategori kata nomina dan tidak mengalami perubahan kategori kata. Kata dominasi diserap dari kata bahasa Inggris domination. Kata dominasi mengalami proses penyesuaian ejaan dalam bahasa Indonesia dan termasuk kata bentukan dengan cara menambahkan awalan pada bentuk dasarnya. Kata ini terbentuk dari imbuhan akhiran (sufiks) asing bahasa Inggris yang diserap secara utuh dalam bahasa Indonesia dan akhirnya mengalami penyesuaian huruf dari -tion menjadi -si. Kata logistik termasuk kategori kata nomina dan tidak mengalami perubahan kategori kata.

Data 2 berupa Kata logistik diserap dari kata bahasa Inggris logistics. Kata ini terbentuk dari imbuhan akhiran (sufiks) asing bahasa Inggris yang diserap secara utuh dalam bahasa Indonesia dan akhirnya mengalami penyesuaian huruf dari -ics menjadi -ik.

Data 3 berupa Kata investasi termasuk kategori kata nomina dan tidak mengalami perubahan kategori kata. Kata investasi diserap dari kata bahasa Inggris investation. Kata investasi mengalami proses penyesuaian ejaan dalam bahasa Indonesia dan termasuk kata bentukan dengan cara menambahkan awalan pada bentuk dasar. Kata investasi diserap dari kata bahasa Inggris investation. Kata ini terbentuk dari imbuhan akhiran (sufiks) asing bahasa Inggris yang diserap secara utuh dalam bahasa Indonesia dan akhirnya mengalami penyesuaian huruf dari -tion menjadi -si.

Data 4 berupa Kata simbiosis termasuk kategori kata nomina dan tidak mengalami perubahan kategori kata. Kata simbiosis mengalami proses penyesuaian ejaan dalam bahasa Indonesia. Kata simbiosis ini berasal dari bahasa Inggris symbiosis dan kata ini akan mengalami penyesuaian ejaan, yakni dari $-y$ menjadi $-i$.

Data 5 berupa kata sensasi termasuk kategori kata nomina dan tidak mengalami perubahan kategori kata. Kata sensation mengalami proses penyesuaian ejaan dalam bahasa Indonesia dan termasuk kata bentukan dengan cara menambahkan awalan pada bentuk dasar. Katasensasi diserap dari kata bahasa

Gigit Mujianto, Sudjalil, Tipe modifikasi fonem kata serapan asing ke dalam bahasa Indonesia pada surat kabar online 
Inggris sensation. Kata ini terbentuk dari imbuhan akhiran (sufiks) asing bahasa Inggris yang diserap secara utuh dalam bahasa Indonesia dan akhirnya mengalami penyesuaian huruf dari -tion menjadi -si.

Data 6 berupa kata informasi termasuk kategori kata nomina dan tidak mengalami perubahan kategori kata. Kata informasi diserap dari kata bahasa Inggris information. Kata ini terbentuk dari imbuhan akhiran (sufiks) asing bahasa Inggris yang diserap secara utuh dalam bahasa Indonesia dan akhirnya mengalami penyesuaian huruf dari -tion menjadi -si.

Data 7 berupa kata potensi termasuk kategori kata nomina dan tidak mengalami perubahan kategori kata. Kata potensi diserap dari kata bahasa Inggris potency. Kata potensi ini terbentuk dari imbuhan akhiran (sufiks) asing bahasa Inggris yakni -y yang diserap secara utuh dalam bahasa Indonesia dan mengalami penyesuaian ejaan dari $-y$ menjadi $-i$.

Data 8 berupa kata divisi termasuk kategori kata nomina dan tidak mengalami perubahan kategori kata. Kata divisi diserap dari kata bahasa Inggris division. Kata ini terbentuk dari imbuhan akhiran (sufiks) asing bahasa Inggris yang diserap secara utuh dalam bahasa Indonesia dan akhirnya mengalami penyesuaian huruf dari -sion menjadi -si. Bentuk kata serapan yang berasal dari kata asing bersufiks banyak ditemui dalam penelitian ini. Proses modifikasi fonem /-tion/ menjadi /-si/ antara lain kata-kata yang banyak ditemukan dalam penelitian ini. Proses modifikasi fonem dari sufiks asing ini tidak mengubah kelas kata atau makna.

Temuan penelitian ini serupa dengan penelitian yang dilakukan oleh (Herniti, 2006; Hidayah et al., 2018; Sundasewu, 2015) yang menyimpulkan bahwa beberapa kata serapan asing merupakan penyesuaian sufiks dalam bahasa Inggris atau bahasa asing lainnya. Setiap bahasa yang bertipologi aglutinatif akan membentuk kata dasarnya menjadi kata bentukan. Proses pembentukan kata dasar ini akan berdampak pada berubahnya kelas kata. Terkait dengan temuan tipe proses modifikasi kata serapan ke dalam bahasa Indonesia, (IInran, 2005; Nafisah, 2017) mengatakan bahwa kata serapan yang telah dilakukan berada dalam kondisi bilingual pembawa kata serapan sangat rendah penguasaan terhadap bahasa asingnya, maka akan terjadi penyelarasan secara fonologis, morfologis, leksikal, dan sintaksis ke dalam bahasa penerima.

Tipe 5: Tipe Jejeran Konsonan atau Vokal Kembar (TJKVK)

Tabel 5

Tipe Jejeran Konsonan atau Vokal Kembar (TJKVK)

\begin{tabular}{|c|c|}
\hline No & Data \\
\hline $\mathrm{I}$ & spontan $\leftarrow$ spontaan \\
\hline 2 & komisioner $\leftarrow$ commissioner \\
\hline 3 & akunњaccount \\
\hline 4 & ilegak illegal \\
\hline 5 & Kamis $\leftarrow$ khamiis \\
\hline
\end{tabular}

Sebutan jejeran konsonan atau vokal hampir sama dengan gugus fonem. Yang dimaksud jejeran konsonan atau vokal adalah deret konsonan atau vokal yang sama (kembar) dalam suatu kata apakah berposisi di awal, tengah, atau akhir. Tipe $5(\mathrm{TJKVK})$ ini banyak ditemukan dalam penelitian ini, tetapi bentukan kata ini tidak mengubah kelas kata atau makna. Kata-kata yang termasuk dalam tipe ini sebagaimana Tabel 5. Proses modifikasi jejeran konsonan atau vokal kembar dipaparkan sebagai berikut ini.

Data I berupa kata spontan termasuk kategori kata adverbia dan tidak mengalami perubahan kategori kata. Kata spontaan mengalami proses penyesuaian ejaan dalam bahasa Indonesia. Kata spontan ini berasal dari kata spontaan dalam bahasa Inggris dan kata ini akan mengalami penyesuaian ejaan, yakni dari /-aa/menjadi / -a/. Penulisan kata spontan sudah sesuai dengan Pedoman Umum Ejaan Bahasa Indonesia dan Pedoman Pembentukan Istilah.

Data 2 berupa kata komisioner termasuk kategori kata nomina dan tidak mengalami perubahan kategori kata. Kata commissioner mengalami proses penyesuaian ejaan dalam bahasa Indonesia. Kata 
komisioner ini berasal dari kata dalam bahasa Inggris commissioner yang mengalami penyesuaian ejaan dalam bahasa Indonesia, yakni dari / $-c /$ menjadi / $-k /$, dan konsonan kembar di dalam kata ini mengalami penyatuan, yakni /-ss/ menjadi /-s/.

Data 3 berupa kata akun termasuk kategori kata nomina dan tidak mengalami perubahan kategori kata. Kata akun diserap dari kata bahasa Inggris account. Kata account ini memiliki gugus konsonan (kluster) pada akhir kata dan diserap serta mengalami penyesuaian ejaan dalam bahasa Indonesia dari $-n t$ menjadi $-n$. Selain itu, kata account juga mengalami penyesuaian ejaan dalam bahasa Indonesia yakni konsonan kembar /-cc/ menjadi /-k/, dan jejeran dua vokal/-ou/ dari/-u/ dalam bahasa Indonesia. Penulisan kata konsep sudah sesuai dengan Pedoman Umum Ejaan Bahasa Indonesia dan Pembentukan Istilah.

Data 4 berupa kata ilegal termasuk kategori kata adverbia dan tidak mengalami perubahan kategori kata. Kata illegal mengalami proses penyesuaian ejaan dalam bahasa Indonesia. Kata illegal ini berasal dari kata dalam bahasa Inggris illegal yang mengalami penyesuaian ejaan dalam bahasa Indonesia, yakni dari /-11/ menjadi /-1/. Konsonan kembar menjadi satu huruf konsonan kecuali jika terdapat pasangan yang dapat menimbulkan kekeliruan makna.

Data 5 berupa kata kamis termasuk kategori kata nomina dan tidak mengalami perubahan kategori kata. Kata kamiis mengalami proses penyesuaian ejaan dalam bahasa. Kata kamis ini berasal dari kata dalam bahasa Arab kamiis yang mengalami penyesuaian ejaan dalam bahasa Indonesia, yakni dengan cara menambahkan huruf /-i/. Penulisan kata kamis sudah sesuai dengan Pedoman Umum Ejaan Bahasa Indonesia dan Pembentukan Istilah.

Temuan penelitian ini serupa dengan penelitian yang dilakukan oleh (Herniti, 2006; Hidayah et al., 2018; Sundasewu, 2015) yang menyimpulkan bahwa beberapa kata serapan asing merupakan deret konsonan atau vokal yang sama (kembar) dalam suatu kata apakah berposisi di awal, tengah, atau akhir. Terkait dengan temuan tipe proses modifikasi kata serapan ke dalam bahasa Indonesia, (IInran, 2005; Nafisah, 2017) mengatakan bahwa kata serapan yang telah dilakukan berada dalam kondisi bilingual pembawa kata serapan sangat rendah penguasaan terhadap bahasa asingnya, maka akan terjadi penyelarasan secara fonologis, morfologis, leksikal, dan sintaksis ke dalam bahasa penerima.

\section{Tipe 6: Tipe Gabung I (TPE+TPGF)}

\begin{tabular}{|c|c|}
\hline \multicolumn{2}{|c|}{$\begin{array}{c}\text { Tabel } 6 \\
\text { Tipe Gabung I (TPE+TPGF) }\end{array}$} \\
\hline No & Data \\
\hline $\mathrm{I}$ & atlet $\leftarrow$ athlete \\
\hline 2 & pasien $\leftarrow$ patient \\
\hline 3 & sif $\leftarrow$ shift \\
\hline 4 & proses $\leftarrow$ process \\
\hline 5 & kontak $\leftarrow$ contact \\
\hline 6 & krusiak $\leftarrow$ crucial \\
\hline 7 & teori $\leftarrow$ theory \\
\hline 8 & manajemen $\leftarrow$ management \\
\hline 9 & konsultan $\leftarrow$ consultant \\
\hline
\end{tabular}

Selain pemaparan tipe-tipe modifikasi kata serapan pada Tipe I-Tipe 5, berikut ini dipaparkan tipe gabungan. Tipe gabung I merupakan pola modifikasi fonem asing yang dilakukan dengan cara menyesuaikan ejaan dan menyesuaikan gabungan fonem. Gabungan fonem yang dimaksud dalam penelitian ini adalah penyesuaian terjadi pada jejeran konsonan atau vokal pada satu suku kata. Tipe gabungan ini muncul sebagai akibat proses modifikasi kata serapan asing yang tidak dapat dilakukan secara langsung atau satu tahap. Bentukan kata serapan dari hasil penggabungan beberapa tipe ini banyak ditemui dalam penelitian ini. Barangkali banyak penutur bahasa yang tidak sadar bahwa kata yang digunakan baik secara lisan maupun tulis berasal dari kata asing yang telah melalui proses modifikasi lebih 
dari dua tahapan. Kata serapan bahasa Indonesia yang ditemukan dalam penelitian ini seperti pada Tabel 6. Proses modifikasi masing-masing kata serapan tersebut dipaparkan sebagai ini.

Data I berupa kata atlet tergolong kategori kata nomina dan tidak mengalami perubahan kategori kata. Kata atlet ini diserap dari kata athletedalam bahasa Inggris dan diserap ke dalam bahasa Indonesia melalui dua tahap. Proses modifikasi yang dilakukan pada kata athlete yakni, (I) mengadakan penyesuaian dari / - th/ menjadi / - t/ dan (2) menanggalkan fonem / e/ pada akhir kata. Penulisan kata atlet ini sudah sesuai dengan kaidah penulisan pada Kamus Besar Bahasa Indonesia atau merujuk pada Pedoman Pembentukan Istilah.

Data 2 berupa kata pasien kategori kata nomina dan tidak mengalami perubahan kategori kata. Kata pasien berasal dari kata patient dalam bahasa Belanda dan kata ini mengalami proses penyesuaian ejaan dalam bahasa Indonesia dan penyesuaian gugus konsonan di akhir kata. Proses modifikasi yang dilakukan pada kata patient, yakni (I) mengadakan penyesuaian fonem / $n t /$ menjadi / $n /$ dan (2) mengadakan penyesuaian ejaan dari / $\mathrm{t} / \mathrm{menjadi} / \mathrm{-s} /$. Penulisan kata pasien sudah sesuai dengan penulisan di Kamus Besar Bahasa Indonesia atau merujuk pada Pedoman Pembentukan Istilah.

Data 3 berupa kata sif termasuk kategori kata ajektiva dan tidak mengalami perubahan kategori kata. Kata sif mengalami proses penyesuaian ejaan dalam bahasa Indonesia. Kata sif ini berasal dari kata shift dalam bahasa Inggris, ketika diserap ke dalam bahasa Indonesia mengalami penyesuaian ejaan, yakni (I) dari fonem/-ft/ menjadi /-f/ dan (2) fonem / sh-/ menjadi / s-/.

Data 4 berupa kata proses termasuk kategori kata nomina proses mengalami proses penyesuaian ejaan dalam bahasa Indonesia. Kata proses ini berasal dari kata process dalam bahasa Inggris dan kata ini akan mengalami penyesuaian ejaan, yakni dari / $-c /$ menjadi / $-s /$. Selain itu, kata process mengandung konsonan kembar /-ss/ akan menjadi /-s/ dalam bahasa Indonesia.

Data 5 berupa kata kontak termasuk kategori kata verba dan tidak mengalami perubahan kategori kata. Katacontact mengalami proses penyesuaian ejaan dalam bahasa Indonesia. Kata kontak diserap dari kata bahasa Inggris contact. Kata contact ini memiliki gugus konsonan (kluster) pada akhir kata dan diserap mengalami penyesuaian ejaan dalam bahasa Indonesia dari / $-c t /$ menjadi / $-k /$. Selain itu, kata contact juga mengalami penyesuaian ejaan yakni dari /-c/ menjadi /-k/ dalam bahasa Indonesia.

Data 6 berupa kata krusial termasuk kategori kata adverbia dan tidak mengalami perubahan kategori kata. Kata krusial diserap dari kata bahasa Inggris crucial. Kata crucial mengalami proses penyesuaian ejaan dalam bahasa Indonesia baik konsonan, gugus konsonan di awal kata. Kata crucial ini mengalami penyesuaian ejaan dalam bahasa Indonesia yakni gugus konsonan pada awal / cr-/ mengalami perubahan menjadi / kr-/, dan penyesuaian ejaan dari /-c/ menjadi /-s/.

Data 7 berupa kata teori termasuk kategori kata nomina dan tidak mengalami perubahan kategori kata. Kata theory mengalami proses penyesuaian ejaan dalam bahasa Indonesia. Kata teori ini berasal dari kata dalam bahasa Inggris theory yang mengalami penyesuaian ejaan dalam bahasa Indonesia, yakni dari /-th/ menjadi /-t/, dan /-y/menjadi /-i/. Penulisan kata teori sudah sesuai dengan Pedoman Umum Ejaan Bahasa Indonesia dan Pembentukan Istilah.

Data 8 berupa kata manajemen termasuk kategori kata nomina dan tidak mengalami perubahan kategori kata. Kata manajemen diserap dari kata bahasa Inggris yaitu management. Kata management ini memiliki gugus konsonan (kluster) pada akhir kata dan diserap mengalami penyesuaian ejaan dalam bahasa Indonesia dari / $n t /$ menjadi / $n /$. Selain itu, kata management juga mengalami penyesuaian ejaan dalam bahasa Indonesia yakni konsonan kembar /-g/ menjadi /-j/.

Data 9 berupa kata konsultan termasuk kategori kata nomina dan tidak mengalami perubahan kategori kata. Kata konsultan berasal dari kata consultant dari bahasa Inggris dan mengalami proses penyesuaian ejaan dalam bahasa Indonesia. Kata consultant ini bergugus konsonan (kluster) pada akhir kata dan diserap mengalami penyesuaian ejaan dalam bahasa Indonesia dari / $n t /$ menjadi / $-n /$. Selain itu, kata consultant juga mengalami penyesuaian ejaan yakni dari /-c/ menjadi/-k/, dan dalam bahasa Indonesia. Penulisan kata konsultan sudah sesuai dengan Pedoman Umum Ejaan Bahasa Indonesia dan Pedoman Pembentukan Istilah. 
Kata serapan yang bertipe gabungan I merupakan kata penyerapan fonem yang dilakukan melalui dua tahap yakni tahap penyesuaian fonem dapat berupa vokal atau konsonan dan tahap berikutnya adalah penyesuaian gugus fonem yang dapat berada di awal, tengah, atau akhir kata. Tipe gabungan I ini banyak ditemukan dalam penelitian ini terutama yang berasal dari bahasa Inggris.

Temuan penelitian ini serupa dengan penelitian yang dilakukan oleh (Herniti, 2006; Hidayah et al., 2018; Sundasewu, 2015) yang menyimpulkan bahwa beberapa kata serapan asing merupakan pola modifikasi fonem asing yang dilakukan dengan cara menyesuaikan ejaan dan menyesuaikan gabungan fonem. Gabungan fonem yang dimaksud dalam penelitian ini adalah penyesuaian terjadi pada jejeran konsonan atau vokal pada satu suku kata. Terkait dengan temuan tipe proses modifikasi kata serapan ke dalam bahasa Indonesia, (IInran, 2005; Nafisah, 2017) mengatakan bahwa kata serapan yang telah dilakukan berada dalam kondisi bilingual pembawa kata serapan sangat rendah penguasaan terhadap bahasa asingnya, maka akan terjadi penyelarasan secara fonologis, morfologis, leksikal, dan sintaksis ke dalam bahasa penerima.

\section{Tipe 7: Tipe Gabung II (TPE+TPSA)}

Tabel 7

\begin{tabular}{|c|c|}
\hline \multicolumn{2}{|c|}{ Tipe Gabung II (TPE+TPSA) } \\
\hline No & Data \\
\hline $\mathrm{I}$ & asumsiŁassumption \\
\hline 2 & aktivitas $\longleftarrow$ activity \\
\hline 3 & lokasi $\leftarrow$ location \\
\hline 4 & transaksiŁ transaction \\
\hline 5 & berkualitas $\leftarrow$ quality \\
\hline 6 & karakteristik $\leftarrow$ characteristics \\
\hline 7 & diskusi $\leftarrow$ discussition \\
\hline
\end{tabular}

Tipe gabung II merupakan pola modifikasi fonem asing yang dilakukan dengan cara menyesuaikan ejaan dan menyesuaikan sufiks (akhiran) asing. Sufiks asing merupakan imbuhan akhir pada bentuk dasar. Sufiks dalam bahasa Inggris atau bahasa asing lainnya tentu saja berbeda. Setiap bahasa yang bertipologi aglutinatif akan membentuk kata dasarnya menjadi kata bentukan. Proses pembentukan kata dasar ini akan berdampak pada berubahnya kelas kata atau tidak. Proses modifikasi fonem yang berasal dari sufiks asing ini berbeda dengan sufiks internal dalam suatu bahasa. Modifikasi sufiks asing yang berasal dari bahasa Inggris ke bahasa Indonesia tidak mengubah kelas kata atau maknanya. Kata serapan bahasa Indonesia yang bertipe gabung II banyak ditemukan dalam penelitian ini sebagaimana pada Tabel 7 . Tahapan masing-masing kata serapan yang bertipe gabung II dipaparkan sebagai berikut ini.

Data I berupa kata asumsi termasuk kategori kata nomina dan tidak mengalami perubahan kategori kata. Kata asumsi diserap dari kata bahasa Inggris assumption. Kata ini terbentuk dari imbuhan akhiran (sufiks) asing bahasa Inggris yang diserap secara utuh dalam dalam bahasa Indonesia dan akhirnya mengalami penyesuaian huruf dari /-tion/ menjadi /-si/. Selain itu, kata asumsi berasal dari assumption yang memiliki konsonan kembar/-ss/ dan akan menjadi satu huruf konsonan /-s /dalam bahasa Indonesia. Posisi fonem kembar dalam bahasa Inggris cukup banyak. Proses modifikasi fonem kembar bahasa Indonesia menjadi luluh atau menjadi fonem yang sama.

Data 2 berupa kata aktivitas termasuk kategori kata nomina dan tidak mengalami perubahan kategori kata. Kata aktivitas ini berasal dari kata activity dalam bahasa Inggris dan kata ini mengalami penyesuaian ejaan dan penyesuaian sufiks asing, yakni penyesuaian fonem /-c-/ menjadi /-k-/ dan tahap berikutnya menyesuaikan sufiks/-ity/ menjadi/-itas/.

Data 3 berupa kata lokasi termasuk kategori kata nomina dan tidak mengalami perubahan kategori kata. Kata lokasi diserap dari kata location dalam bahasa Inggris. Kata ini terbentuk dari imbuhan akhiran (sufiks) asing bahasa Inggris yang diserap secara utuh dalam dalam bahasa Indonesia dan akhirnya mengalami penyesuaian huruf dari /-tion/ menjadi/-si/. Selain itu, kata lokasi juga mengalami 
penyesuaian ejaan yakni dari /-c/ menjadi /-k/ dalam bahasa Indonesia. Penulisan lokasi sudah sesuai dengan Pedoman Umum Ejaan Bahasa Indonesia dan Pembentukan Istilah.

Data 4 berupa kata transaksi termasuk kategori kata nomina dan tidak mengalami perubahan kategori kata. Kata transaksi diserap dari kata transaction dalam bahasa Inggris. Kata ini terbentuk dari imbuhan akhiran (sufiks) asing bahasa Inggris yang diserap secara utuh dalam bahasa Indonesia dan akhirnya mengalami penyesuaian huruf dari/-tion/menjadi/-si/. Selain itu, kata transaction juga mengalami penyesuaian ejaan yakni dari / $\mathrm{c} /$ menjadi /-k/ dalam bahasa Indonesia. Penulisan transaksi sudah sesuai dengan Pedoman Umum Ejaan Bahasa Indonesia dan Pembentukan Istilah.

Data 5 berupa kata kualitas termasuk kategori kata adverbia dan tidak mengalami perubahan kategori kata. Kata kualitas diserap dari kata quality dalam bahasa Inggris. Kata ini terbentuk dari imbuhan akhiran (sufiks) asing bahasa Inggris yang diserap secara utuh dalam bahasa Indonesia dan akhirnya mengalami penyesuaian sufiks /-ity/menjadi/-itas/. Selain itu, kata aktivitas ini juga mengalami penyesuaian ejaan yakni dari /-q/ menjadi /-k/ dalam bahasa Indonesia. Penulisan kualitas sudah sesuai dengan Pedoman Umum Ejaan Bahasa Indonesia dan Pedoman Pembentukan Istilah.

Data 6 berupa kata karakteristik termasuk kategori kata nomina dan tidak mengalami perubahan kategori kata. Kata karakteristik diserap dari kata characteristics dalam bahasa Inggris. Kata ini terbentuk dari imbuhan akhiran (sufiks) asing bahasa Inggris yang diserap secara utuh dalam bahasa Indonesia dan akhirnya mengalami penyesuaian sufiks /-ics/menjadi / -ik/. Selain itu, kata karakteristik juga mengalami penyesuaian ejaan yakni dari /-ch/ menjadi /-k/ dalam bahasa Indonesia. Penulisan kata karakteristik sudah sesuai dengan Pedoman Umum Ejaan Bahasa Indonesia dan Pedoman Pembentukan Istilah.

Data 7 berupa kata diskusi termasuk kategori kata verba dan tidak mengalami perubahan kategori kata. Kata diskusi diserap dari kata discussition bahasa Inggris. Kata diskusi ini terbentuk dari imbuhan akhiran (sufiks) asing bahasa Inggris yang diserap secara utuh dalam bahasa Indonesia. Proses modifikasi kata discussition dilakukan melalui tiga tahapan, yakni (a) mengadakan penyesuaian sufiks (akhiran) / tion/menjadi /-si/, (b) mengadakan penyesuaian ejaan /-c/ menjadi/-k/, dan (c) mengadakan penyatuan konsonan kembar /-ss/ menjadi /-s/. Untuk itu, penulisan diskusi sudah sesuai dengan Pedoman Umum Ejaan Bahasa Indonesia dan Pembentukan Istilah serta Kamus Besar Bahasa Indonesia.

Temuan penelitian ini serupa dengan penelitian yang dilakukan oleh (Herniti, 2006; Hidayah et al., 2018; Sundasewu, 2015) yang menyimpulkan bahwa beberapa kata serapan asing merupakan pola modifikasi fonem asing yang dilakukan dengan cara menyesuaikan ejaan dan menyesuaikan sufiks (akhiran) asing. Terkait dengan temuan tipe proses modifikasi kata serapan ke dalam bahasa Indonesia, (IInran, 2005; Nafisah, 2017) mengatakan bahwa kata serapan yang telah dilakukan berada dalam kondisi bilingual pembawa kata serapan sangat rendah penguasaan terhadap bahasa asingnya, maka akan terjadi penyelarasan secara fonologis, morfologis, leksikal, dan sintaksis ke dalam bahasa penerima.

\section{Tipe 8: Tipe Gabung III (TPGF+ TJKVK)}

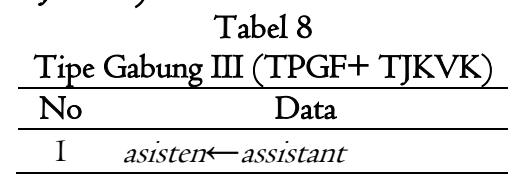

Tipe gabung III merupakan pola modifikasi fonem asing yang dilakukan dengan cara menyesuaikan gabungan fonem dan menyesuaikan jejeran vokal atau konsonan kembar dalam bahasa Inggris atau bahasa asing lainnya. Setiap bahasa yang bertipologi sufiks asing merupakan imbuhan akhir pada bentuk dasar. Sufiks dalam bahasa aglutinatif akan membentuk kata dasarnya menjadi kata bentukan. Proses pembentukan kata dasar ini akan berdampak pada berubahnya kelas kata atau tidak. Proses modifikasi fonem yang berasal dari sufiks asing ini berbeda dengan sufiks internal dalam suatu bahasa. Modifikasi sufiks asing yang berasal dari bahasa Inggris ke bahasa Indonesia tidak mengubah kelas kata atau maknanya. Kata serapan bahasa Indonesia yang bertipe gabung III sebagaimana Tabel 8. 
Data I berupa kata asisten sebagaimana tersebut di atas termasuk kategori kata nomina dan tidak mengalami perubahan kategori kata. Kata asisten berasal dari kata assistant dari bahasa Inggris dan mengalami proses penyesuaian ejaan dalam bahasa Indonesia. Kata assistent ini memiliki gugus konsonan (kluster) pada akhir kata. Proses modifikasi fonem pada kata assistent melalui dua tahapan, yaitu menyesuaikan fonem /-nt/ menjadi /-n/ dan mengadakan penyesuaian konsonan kembar (jejeran dua konsonan kembar)/-ss/ menjadi /-s/ dalam bahasa Indonesia. Penulisan kata asisten sudah sesuai dengan Pedoman Umum Ejaan Bahasa Indonesia dan Pedoman Pembentukan Istilah.

Temuan penelitian ini serupa dengan penelitian yang dilakukan oleh (Herniti, 2006; Hidayah et al., 2018; Sundasewu, 2015) yang menyimpulkan bahwa beberapa kata serapan asing merupakan pola modifikasi fonem asing yang dilakukan dengan cara menyesuaikan gabungan fonem dan menyesuaikan jejeran vokal atau konsonan kembar dalam bahasa Inggris atau bahasa asing lainnya. Terkait dengan temuan tipe proses modifikasi kata serapan ke dalam bahasa Indonesia, (IInran, 2005; Nafisah, 20I7) mengatakan bahwa kata serapan yang telah dilakukan berada dalam kondisi bilingual pembawa kata serapan sangat rendah penguasaan terhadap bahasa asingnya, maka akan terjadi penyelarasan secara fonologis, morfologis, leksikal, dan sintaksis ke dalam bahasa penerima

\section{SIMPULAN}

Tipe modifikasi fonem pada kata serapan bahasa asing ke dalam bahasa Indonesia yang telah ditemukan dalam penelitian ini meliputi (I) tipe tanpa penyesuaian ejaan, (2) tipe penyesuaian ejaan, (3) tipe penyesuaian gugus fonem, (4) tipe penyesuaian sufiks asing, (5) tipe jejeran konsonan atau vokal kembar, (6) tipe gabung I, (7) tipe gabung II, dan (8) tipe gabung III. Tipe-tipe tersebut merupakan hasil analisis terhadap topografi kata serapan. Tipe-tipe tersebut merupakan hasil analisis terhadap topografi kata serapan dan akan terus mengalami perkembangan sejalan dengan perkembangan bahasa masyarakatnya, khususnya di bidang jurnalistik. Perkembangan kosakata serapan perlu dilakukan untuk melengkapi kekurangan-kekurangan jenis kata, ungkapan, istilah yang mampu mewadahi dan mengungkapkan aspek-aspek kehidupan, kejiwaan masyarakatnya, serta ilmu pengetahuan dan teknologi.

\section{UCAPAN TERIMA KASIH}

Penulis mengucapkan terima kasih kepada DPPM Universitas Muhammadiyah Malang yang telah memberikan dukungan dalam penelitian ini, serta semua pihak yang telah berkontribusi dalam penelitian ini, sehingga penelitian ini dapat terlaksana dan diselesaikan dengan baik.

\section{DAFTAR PUSTAKA}

Arifin, I., Wibawa, B., \& Syahrial, Z. (2019). The role of facilitators in a collaborative online learning environment. International Journal of Innovative Technology and Exploring Engineering, 8(6), 72-75. Retrieved from https://www.scopus.com/inward/record.uri?eid=2-s2.085068555965\&partnerID $=408 \mathrm{md} 5=563 \mathrm{dc} 9 \mathrm{~b} 7 \mathrm{c} 97 \mathrm{a} 517$ fae 5669634b4a4fd9

Cooke, M., Aubanel, V., \& García Lecumberri, M. L. (2019). Combining spectral and temporal modification techniques for speech intelligibility enhancement. Computer Speech and Language, 55, 26-39. https://doi.org/I0.1016/j.cs1.2018.10.003

Fatmasari, R. K. (2020). Perubahan fonem pada anak usia 2-4 tahun di PAUD Anna Husada Jl. Brantas No. IA Perum Candra Land Mlajah Bangkalan (kajian fonoligis). Jurnal Sastra Aksara, 8(I), 4053. https://doi.org/I0.3I597/jsa.v8iI.45

Galovic, F. (2017). The phonological system of the local dialect of Pražnica. Fluminensia, 29(2), 9IIIO. https://doi.org/I0.3I820/f.29.2.5

Gjerga, E., Dugourd, A., Tobalina, L., Sousa, A., \& Saez-Rodriguez, J. (202I). PHONEMeS: Efficient modeling of signaling networks derived from large-scale mass spectrometry data. Journal of Proteome Research. https:/ / doi.org/I0.I02I/acs.jproteome.0c00958

Herniti, E. (2006). Serapan bahasa asing dalam bahasa Indonesia. SOSIO-RELIGIA, 5(4), 657-690. 
Retrieved from https://www.aifis-digilib.com/uploads/I/3/4/6/I3465004/5-4_ening.pdf Hidayah, M., Samingin, F. X., \& Wijayanti, A. (2018). Kata serapan bahasa Arab dalam kosakata bahasa Indonesia sebagai materi pembelajaran ceramah di kelas XI SMA: Kajian bidang fonologi. Repetisi: Riset Pendidikan Bahasa dan Sastra Indonesia, I(2), I00-II2. Retrieved from http://jom.untidar.ac.id/index.php/repetisi/article/view/787

Huilgol, S., Baik, J., \& Shattuck-Hufnagel, S. (2019). A framework for labeling speech with acoustic cues to linguistic distinctive features. Journal of the Acoustical Society of America, I46(2), E6I84E6190. https://doi.org/I0.II2I/I.5I2I7I7

IInran, I. (2005). Kata serapan dalam bahasa Indonesia. In Proceeding, Seminar Nasional PESAT 2005. Jakarta. Retrieved from http://repository.gunadarma.ac.id/278/I/Kata serapan dalam bahasa Indonesia_UG.pdf

Isnaeni, H., Samingin, F. X., \& Wulandari, A. (2020). Kata serapan bahasa Arab ke dalam bahasa Indonesia sebagai bahan ajar teks laporan hasil observasi di SMA. Repetisi: Riset Pendidikan Bahasa dan Sastra Indonesia, 3(2), 59-70. Retrieved from http://jom.untidar.ac.id/index.php/repetisi/article/view/I03I

Khonglah, B. K., Dey, A., \& Prasanna, S. R. M. (2019). Speech enhancement using source information for phoneme recognition of speech with background music. Circuits, Systems, and Signal Processing, 38(2), 643-663. https://doi.org/I0.1007/s00034-018-0873-x

Lazim, N. H. B. M., \& Jaafar, S. R. S. (2018). Deliquidation of Arabic loanwords in kelantan dialect. GEMA Online Journal of Language Studies, I8(4), 236-250. https://doi.org/I0.17576/gema-2018-I804-I5

Lazim, N. H. M., \& Jaafar, S. R. S. (2018). Delikuidasi kata pinjaman Arab dalam dialek Kelantan (Deliquidation of Arabic Loanwords in Kelantan Dialect). GEMA Online $\mathbb{R} J$ ournal of Language Studies, I8(4), 236-250. https://doi.org/I0.I7576/gema-20I8-I804-I5

Mabruroh, K. (2017). Perubahan fonetik pada kata serapan bahasa Arab ke dalam bahasa Jawa dalam bahasa harian. Jurnal Iqra': Kajian Ilmu Pendidikan, 2(2), 305-324. doi: https://doi.org/I0.25217/ji.v2i2.I50

Maneechukate, S. (20I4). Kata serapan bahasa Sanskerta dalam bahasa Indonesia dan bahasa Thai sebagai bahan pengajaran bahasa. Jurnal Kependidikan: Penelitian Inovasi Pembelajaran, 44(2). https://doi.org/https://doi.org/I0.2183I/jk.v44i2.5227

Meysitta, L. (2018). Perkembangan kosakata serapan bahasa asing dalam KBBI. BAPALA, 5(2), I-IO. Retrieved from https://jurnalmahasiswa.unesa.ac.id/index.php/bapala/article/view/23982/21922

Miles, M. B., \& Huberman, A. M. (I994). Qualitative data analysis: An expanded sourcebook. London: SAGE Publications Inc.

Nafisah, S. (2017). Proses fonologis dan pengkaidahannya dalam kajian fonologi generatif. Deiksis, 9(0I), 70-78. https://doi.org/http://dx.doi.org/I0.30998/deiksis.v9i0I.940

Putradi, A. W. A. (2016). Pola-pola perubahan fonem vokal dan konsonan dalam penyerapan kata-kata bahasa asing ke dalam bahasa Indonesia: Kajian fonologi. Jurnal Arbitrer, 3(2), 95II2. https://doi.org/I0.25077/ar.3.2.95-II2.20I6

Putro, D. S., Suryanto, E., \& Sumarwati, S. (2015). Kata serapan pada kolom Iki Lho di Harian Joglosemar (pola dan latar belakang penggunaan). BASASTRA, 3(3), I2-23.

Qashidi, H. (2015). Analisis fonologis dan ortografis kosakata serapan bahasa Prancis dalam bahasa Indonesia. Jurnal Ilmiah Mahasiswa FIB, 2(5), 13-26.

Rafalko, J. (2018). Marking the allophones boundaries based on the DTW algorithm. In 22nd IEEE Signal Processing: Algorithms, Architectures, Arrangements, and Applications, SPA 2018 (Vol. 2018-Septe, pp. 245-249). Faculty of Mathematics and Information Science, Warsaw University of Technology, Warsaw, Poland: IEEE Computer Society. https://doi.org/I0.23919/SPA.2018.8563359 
Rini, E. I. H. A. N. (2018). Kata serapan dalam bahasa Jepang. KIRYOKU, 2(2), 72-77. https://doi.org/ttps://doi.org/I0.I4710/kiryoku.v2i2.72-77

Rohbiah, T. S. (20I7). Perubahan makna kata serapan bahasa Arab dalam bahasa Inggris pada istilah ekonomi. Buletin Al-Turas, 23(2), 319-335. https://doi.org/I0.15408/bat.v23i2.5790

Sakrim, S. (2020). Distribusi, pelepasan, dan perubahan fonem [R] dalam komunikasi anak usia 3 tahun. Stilistika: Jurnal Pendidikan Bahasa dan Sastra, I3(2), 234-242. http://dx.doi.org/I0.3065I/st.vI3i2.4857

Setianingrum, N., \& Hidayat, N. (2019). The development of asset liquidity management learning based on online research and trade as a financial inclusion strategy for students. International Journal of Scientific and Technology Research, 8(8), 9I-96. Retrieved from https://www.scopus.com/inward/record.uri?eid=2-s2.0-

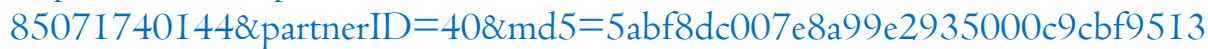

Suartini, N. N. (20I0). GAIRAIGO: Kata serapan bahas asing dalam perkembangan bahasa Jepang. Prasi: Jurnal Bahasa, Seni, dan Pengajarannya, 6(I2). https://doi.org/http:/ /dx.doi.org/I0.23887/prasi.v6iI2.6822

Sudjalil, S. (2018). Tipologi abreviasi dalam surat kabar berbahasa Indonesia. KEMBARA: Jurnal Keilmuan Bahasa, Sastra, dan Pengajarannya (e-Journal), 4(I), 72-85. https://doi.org/https://doi.org/I0.22219/kembara.v4iI.57I9

Sudro, P. N., \& Prasanna, S. R. M. (202I). Modification of misarticulated fricative /s/ in cleft lip and palate speech. Biomedical Signal Processing and Control, 67. https://doi.org/I0.I016/j.bspc.2020.102088

Suharyanto, S. (2015). Perubahan fonem dalam dialek Melayu Ambon. Widyaparwa, 43(I), I524. https://doi.org/I0.26499/wdprw.v43iI.I02

Sundasewu, R. U. (20I5). Analisis kontrasif perubahan fonem pada proses reduplikasi dalam bahasa Jepang dan bahasa Indonesia: Kajian morfofonemik. Edusentris, 2(2), 190-202. https://doi.org/I0.I7509/edusentris.v2i2.I7I

Ubaidillah, I. (2013). Kata serapan bahasa asing dalam Al-Qur'an dalam pemikiran At-thobari. AtTa'dib, 8(I), II9-I32. https://doi.org/http://dx.doi.org/I0.2I I I /at-tadib.v8iI.5I7

Valipur, A. (2018). Comparative studying of sound modification and their variation in the Russian and Persian languages. Russian Language Studies, I6(3), 279-286. https://doi.org/10.22363/2618-8163-2018-I6-3-279-286

Wurianto, A. B. (20I5). Kata serapan bahasa Sanskerta dalam bahasa Indonesia. KEMBARA: Jurnal Keilmuan Bahasa, Sastra, dan Pengajarannya (e-Journal), I(2), I25-I34. https://doi.org/https://doi.org/I0.22219/kembara.vIi2.2610

Yasin, A. (2018). Bahasa Arab dalam bahasa Indonesia (analisis kritis perubahan makna kata serapan bahasa Arab). Diwan: Jumnal Bahasa dan Sastra Arab, 4(I), 44-57. https://doi.org/https://doi.org/I0.24252/diwan.v4iI.4670

Yinghan, G. (2020). Analisis kata-kata serapan dari dialek min nan dalam bahasa Indonesia. Jurnal Pena Indonesia, 6(2), I-22. https://doi.org/http://dx.doi.org/I0.26740/jpi.v6n2.pI-20

Young, J. C., \& Rusli, A. (2019). Review and visualization of Facebook's fasttext pretrained word vector model. In 2019 International Conference on Engineering, Science, and Industrial Applications, ICESI 2019. Universitas Multimedia Nusantara, Tangerang, Banten, Indonesia: Institute of Electrical and Electronics Engineers Inc. doi: https://doi.org/I0.I I09/ICESI.2019.88630I5

Zamrotin, I. M. U. (202I). Analaisis bentuk, perubahan fonem, dan makna kata majemuk dengan unsur bagian tubuh manusia. HIKARI, 5(I), I-9. Retrieved from file:///C:/Users/LENOVO/Downloads/364I3-45960-I-SM.pdf 